\title{
Aspek Hukum Hubungan Kewenangan Vertikal Antara Pemerintah Pusat dan Daerah dalam Tata Kelola Pemerintahan
}

\author{
Legal Aspects of Vertical Authority Relationship between Central and \\ Regional Government in Governance
}

\author{
La Ode Ali Muhamad \\ Kanwil Kemenkumham Sulawesi Tenggara \\ E-mail: laodemuhammafaali@gmail.com \\ Sabaruddin Sinapoy \\ Pascasarjana Universitas Halu Oleo \\ E-mail: sabaruddinsinapoy@yahoo.com \\ La Sensu \\ Pascasarjana Universitas Halu Oleo \\ E-mail: lasensu@uho.ac.id
}

\begin{abstract}
This study aims to analyze the form of vertical relations and authority between the Central and Regional Governments, as well as to examine the legal aspects of the relationship mechanism and the implementation of such vertical authority in government administration according to National Regulation No. 23 of 2014. This study uses a normative legal analysis with a statute approach to describe various legal considerations (juridical) that are appropriate to the various divisions of affairs and authorities between the center and the regional government. The implementation of National Regulation Number 23 of 2014 in the era of decentralization clearly does not reflect broad autonomy because government relations are mostly vertical, so they are considered to have degraded the spirit of regional autonomy, as well as giving rise to juridical problems that have the potential to cause legal problems.
\end{abstract}

Keyword: Government Relations; Authority; Verticalization

Abstrak: Penelitian ini bertujuan untuk menganalisis bentuk hubungan dan kewenangan vertikal antara Pemerintah Pusat dan Daerah, serta mengkaji aspek hukum dari mekanisme hubungan dan pelaksanaan kewenangan vertikal tersebut dalam penyelenggaraan pemerintahan sesuai dengan Undang-Undang Nomor 23 Tahun 2014. Penelitian ini menggunakan analisis hukum normatif dengan pendekatan perundangundangan (statute approach) untuk mendeskripsikan berbagai pertimbangan hukum (yuridis) yang sesuai dengan berbagai pembagian urusan dan kewenangan pemerintahan antara pusat dan daerah. Penerapan Undang-Undang Nomor 23 Tahun 2014 pada era 
desentralisasi ini jelas tidak mencerminkan otonomi yang luas karena hubungan pemerintahan sebagian besar bersifat vertikal sehingga dianggap telah mendegradasi semangat otonomi daerah, serta memunculkan permasalahan yuridis yang berpotensi menimbulkan permasalahan hukum.

Kata kunci: Urusan Pemerintahan; Kewenangan; Vertikalisasi

\section{PENDAHULUAN}

Hubungan tata kelola pemerintahan antara pusat dan daerah terjadi perubahan secara dinamis sejak fase awal reformasi hingga lahirnya Undang-Undang Nomor 23 Tahun 2014 Tentang Pemerintah Daerah. Secara konseptual, berbagai perubahan tersebut jika ditinjau dari aspek hukum berkonsekuensi pada adanya vertikalisasi, sehingga sebagian urusan yang sebelumnya menjadi kewenangan Kabupaten/Kota ataupun Provinsi dipandang kembali diambil alih oleh pemerintah pusat sehingga berdampak pada adanya eksternalitas yang terbilang tidak sedikit. Hal lain juga akan berkonsekuensi terhadap pelaksanaan tugas pokok dan fungsi (tupoksi) secara teknis oleh perangkat organisasi pemerintahan pusat yang berkedudukan di daerah kaitannya dengan pelaksanaan tupoksi organisasi perangkat daerah (OPD) yang secara teknis sama, sehingga yang berisiko menjadi bias/terdegradasi bahkan disfungsi. Sebagai contoh, kewenangan yang selama ini diberikan kepada kabupaten/kota akhirnya mengalami pengalihan atau penarikan ke Provinsi sebagai perpanjangan tangan pemerintah pusat, seperti bidang kehutanan, ESDM, kelautan dan sebagian perikanan, serta pendidikan menengah. Hal ini menurut Ryaas Rasyid ${ }^{1}$ tentu menguatkan indikasi adanya vertikalisasi kewenangan pemerintah pusat melalui pemerintah provinsi. Ekses atau dampak negatif bermunculan dari pengaturan baru ini. Beberapa pengamat bahkan mengatakan undang-undang baru ini menjadi tanda menguatnya kembali rezim sentralisasi (resentralisasi). Menurut Bagir Manan, suatu otonomi dapat digolongkan sebagai otonomi terbatas apabila, Pertama, urusan-urusan rumah tangga daerah ditentukan secara kategoris dan pengembangannya diatur dengan cara-cara tertentu pula, Kedua, apabila sistem supervisi dan pengawasan dilakukan sedemikian rupa sehingga daerah otonom kehilangan kemandirian untuk menentukan secara bebas cara-cara untuk mengatur dan mengurus rumah tangga daerahnya, dan Ketiga, sistem hubungan keuangan antara pusat dan daerah yang menimbulkan hal-hal seperti keterbatasan

1 Ryaas Rasyid, “UU No. 23/2014 Membelokan Arah Otonomi Daerah dari Pakem Reformasi 1999”, Pidato Sebagai Keterangan Ahli Sidang Mahkamah Konstitusi atas Pengajuan Judicial Review atas UU No. 23 Tahun 2014 tentang Pemerintahan Daerah, 14 April 2016. Lihat juga di Widhi Novianto dkk., Isu-isu Strategis Bidang Desentralisasi dan Otonomi Daerah, Jakarta: Pusat Kajian Desentralisasi dan Otonomi Daerah, 2016, hlm. 5. 
kemampuan keuangan asli daerah yang akan membatasi ruang gerak otonomi daerah. ${ }^{2}$ Berlainan dengan konsep otonomi luas yang biasa bertolak dari prinsip semua urusan pemerintahan pada dasarnya menjadi urusan rumah tangga daerah, kecuali yang ditentukan sebagai urusan pemerintah pusat ${ }^{3}$.

Hubungan kewenangan antara pusat dan daerah tentu bertalian dengan pembagian urusan pemerintahan. Secara khusus, pembagian kewenangan antara Pemerintah Pusat dan Pemerintah Daerah saat ini mengacu pada ketentuan di dalam UU No. 23 Tahun 2014 tentang Pemerintahan Daerah sebagai revisi dari undang-undang sebelumnya yakni UU No. 32 Tahun 2004. UU No. 32 Tahun 2004 dilakukan dengan tujuan untuk memperbaiki berbagai kelemahan dari UU No. 32 Tahun 2004 terkait dengan konsep kebijakan desentralisasi dalam negara kesatuan, ketidakjelasan pengaturan dalam berbagai aspek penyelenggaraan pemerintahan daerah, dan hubungan antara pemerintah dengan warga dan kelompok madani. Praktik penyelenggaraan pemerintahan daerah di Indonesia menurut UU No. 32 Tahun 2004 belum sepenuhnya menjamin terwujudnya NKRI yang desentralistis dan mampu menjamin adanya hubungan yang harmonis dan sinergi antar tingkatan dan susunan pemerintahan. Salah satu unsur penting di dalam hubungan pusat-daerah adalah pembagian kewenangan. Secara yuridis pembagian kewenangan ini oleh undang-undang diatur sebagai urusan pemerintahan. Klasifikasi urusan pemerintahan secara khusus diatur dalam ketentuan undang-undang tersebut yang meliputi urusan pemerintahan absolut, urusan pemerintahan konkuren dan urusan pemerintahan umum ${ }^{4}$.

Olehnya itu penulis memandang bahwa perlu dilakukan telaah secara mendalam terkait hubungan vertikal pemerintahan antara Pemerintah Pusat dan Daerah, serta kaitan antara hubungan dan kewenangan vertikal dalam Tata Kelola Pemerintahan antara Pemerintah Pusat dan Daerah dalam perspektif dan pendekatan aspek yuridis dalam hukum formal sebagaimana dianut oleh sistem hukum ketatanegaraan

2 Bagir Manan, Menyongsong Fajar Otonomi Daerah, Yogyakarta: Penerbit Pusat Studi Hukum FH UII, 2001, hlm. 37. Dalam Abdul Rauf Alauddin Said, "Pembagian Kewenangan Pemerintah Pusat-Pemerintah Daerah dalam Otonomi Seluas-Luasnya Menurut UUD 1945”, Fiat Justisia Jurnal Ilmu Hukum Volume 9 No. 4, Oktober-Desember 2015, hlm. 509-510.

3 Ibid., hlm. 37.

4 Naskah Akademik RUU tentang Pemerintahan Daerah, Kementerian Dalam Negeri Republik Indonesia, 2011, dikutip dari www.rumahpemilu.com, diakses tanggal 18 Maret 2014, Dalam Wafia Dhesinta "Pembagian Kewenangan Pusat dan Daerah Berdasarkan UUD 1945 dan Prinsip Otonomi Daerah", Academia.edu, https://www.academia.edu/14842154/pembagian_kewenangan_pusat_dan_daerah_ berdasarkan_uud_1945_dan_prinsip_otonomi_daerah, diakses pada tanggal 26 Januari 2021, hlm 17. 
Republik Indonesia agar tujuan dari lahirnya otonomi daerah dapat secara tepat dilaksanakan.

\section{METODE PENELITIAN}

Penelitian ini menggunakan tipologi penelitian hukum normatif. Penelitian hukum normatif yaitu penelitian hukum sebagai norma. Penelitian hukum dilakukan untuk menghasilkan argumentasi, teori atau konsep hukum sebagai preskripsi untuk menyelesaikan masalah yang dihadapi. Dengan demikian penelitian ini mencakup analisis hukum tertulis yang didahului inventarisasi hukum positif. Hal ini akan menjadi salah satu produk analisa abstraksi dari norma hukum positif. ${ }^{5}$ Tentunya yang berhubungan dengan permasalahan yang akan dibahas oleh penulis dan juga dengan penelitian kepustakaan (library research), yaitu penelitian yang dilakukan dengan mengumpulkan data dari bahan kepustakaan yang berhubungan dengan permasalahan yang diteliti. Penelitian ini menggunakan analisis hukum normatif dengan pendekatan perundang-undangan (statute approach) yang bertujuan untuk mengulas berbagai pertimbangan hukum yang tepat dalam menghadapi problem hukum yang dihadapi ${ }^{6}$.

\section{ANALISIS DAN PEMBAHASAN}

\section{Hubungan Vertikal Penyelenggaraan Pemerintahan Pusat dan Daerah}

\section{Bentuk Hubungan Pemerintah Pusat dan Daerah dalam Undang-Undang Nomor 23 Tahun}

\section{4}

Dengan berlakunya UU No. 23/2014 tentang Pemerintahan Daerah yang baru menggantikan UU No. 32 Tahun 2004 maka ada sejumlah pro dan kontra yang muncul terkait berlakunya UU terebut. Perubahan pada kebijakan desentralisasi otomatis turut mengubah pola penyelenggaraan pemda yang selama ini telah berjalan dan turut mengubah budaya birokrasi daerah dalam melaksanakan pekerjaannya ${ }^{7}$.

Secara yuridis kewenangan adalah hak dan kekuasaan pemerintah yang sah secara hukum, maka dalam konsep Negara hukum (rechstaat) segala tindakan pemerintah yang bersumber dari kewenangannya haruslah bersandarkan pada asas legalitas ${ }^{8}$. Pasal 18A UUD

5 Soentandyo Wingyosoebroto, Penelitian Hukum, Surabaya, Surabaya: Pusat Studi Hukum dan Pembangunan Fakultas Hukum UNAIR, 1974, hlm. 1, 7, dan 8.

6 Peter Mahmud Marzuki, Penelitian Hukum, edisi revisi cetakan Ke-13, Jakarta: Kencana, 2017, hlm. 133.

7 H.R. Ridwan, Hukum Administrasi Negara, Yogyakarta: UII Press, 2003,

8 Ali Marwan Hsb, Keberadaan Mahkamah Konstitusi dan Putusannya, Medan: Enam Media, 2019, hlm 171. 
NRI 1945 memberikan dasar konstitusional bagi pengaturan hubungan wewenang antara pemerintah pusat dan pemerintah daerah sebagai berikut:

1. Hubungan wewenang antara pemerintah pusat dan pemerintah daerah provinsi, kabupaten, dan kota, atau antara provinsi dan kabupaten dan kota, diatur dengan undang-undang dengan memperhatikan kekhususan dan keragaman daerah.

2. Hubungan keuangan, pelayanan umum, pemanfaatan sumber daya alam dan sumber daya lainnya antara pemerintah pusat dan pemerintah daerah diatur dan dilaksanakan secara adil dan selaras berdasarkan undang-undang.

Berdasarkan ketentuan tersebut, untuk mengatur hubungan kewenangan pusat dan daerah yang diamanatkan UUD NRI 1945 dapat dilakukan melalui berbagai peraturan perundang-undangan, baik yang secara khusus mengatur otonomi daerah, atau tersebar di berbagai peraturan perundang-undangan. Hal ini didasarkan pada kenyataan empiris dan yuridis yang menggambarkan bahwa materi dan cakupan pengaturan tentang hubungan pusat dan daerah tidak dapat diatur oleh satu undang-undang. Hubungan keuangan, pelayanan umum, serta pemanfaatan sumber daya terkait dengan berbagai sektor lain yang tidak dapat diperlakukan secara sama. Oleh karena itu, diperlukan adanya undang-undang yang khusus mengatur hubungan kewenangan pusat dan daerah secara umum serta dibutuhkan pula berbagai undang-undang lainnya yang berkaitan dengan otonomi daerah. 9

Secara khusus, pembagian kewenangan antara Pemerintah Pusat dan Pemerintah Daerah saat ini mengacu pada ketentuan di dalam UU No. 23 Tahun 2014 tentang Pemerintahan Daerah sebagai revisi dari undang-undang sebelumnya yakni UU No. 32 Tahun 2004. Praktik penyelenggaraan pemerintahan daerah di Indonesia menurut UU No. 32 Tahun 2004 belum sepenuhnya menjamin terwujudnya NKRI yang desentralistis dan mampu menjamin adanya hubungan yang harmonis dan sinergi antar tingkatan dan susunan pemerintahan ${ }^{10}$.

\section{Pembagian Urusan dalam Hubungan Pemerintah Pusat dan Daerah dalam Undang-}

\section{Undang Nomor 23 Tahun 2014}

Salah satu unsur penting di dalam hubungan pusat-daerah adalah pembagian kewenangan. Secara yuridis pembagian kewenangan ini oleh undang-undang diatur sebagai urusan pemerintahan. Klasifikasi urusan pemerintahan secara khusus diatur dalam Pasal 9 yang

9 Abdul Rauf Alauddin Said, Op. cit., hlm. 520.

10 Naskah Akademik RUU tentang Pemerintahan Daerah, Kementerian Dalam Negeri Republik Indonesia, 2011, dikutip dari www.rumahpemilu.com, diakses tanggal 30 Januari 2016. 
meliputi urusan pemerintahan absolut, urusan pemerintahan konkuren dan urusan pemerintahan umum. Ketentuan tersebut secara rinci diatur sebagai berikut:

\section{Urusan Pemerintahan Absolut}

Urusan pemerintahan absolut dimaksudkan sebagai urusan pemerintahan yang sepenuhnya menjadi kewenangan pusat dan oleh karena itu tidak berhubungan dengan asas desentralisasi atau otonomi. Urusan Pemerintahan absolut yang sepenuhnya menjadi kewenangan Pemerintah Pusat dalam Pasal 10 ayat (1) antara lain: 1) politik luar negeri; 2) keamanan; 3) yustisi; 4) moneter dan fiskal nasional; dan 5) agama. Dalam ketentuan selanjutnya, diatur bahwa Pemerintah Pusat dalam melaksanakan kewenangan absolut ini dapat melaksanakan sendiri atau melimpahkannya kepada Pemerintah daerah berdasarkan asas dekonsentrasi.

\section{Urusan Pemerintahan Konkuren}

Sebagaimana bunyi Pasal 9 ayat (3) UU No. 23 Tahun 2014, urusan pemerintahan konkuren dimaksudkan sebagai urusan pemerintahan yang dibagi antara pemerintah pusat dan pemerintah daerah yaitu provinsi dan kabupaten/kota. Selanjutnya di ayat (4), menyatakan bahwa urusan konkuren yang diserahkan kepada daerah menjadi dasar bagi pelaksanaan Otonomi Daerah. Urusan konkuren tersebut kemudian dibagi menjadi urusan wajib dan urusan pilihan. ${ }^{11}$

\section{Urusan Pemerintahan Umum}

Pemerintah pusat juga diberikan kewenangan dalam urusan pemerintahan umum yang diatur dalam Pasal 25 ayat (1) yang antara lain:

a. pembinaan wawasan kebangsaan dan ketahanan nasional dalam rangka memantapkan pengamalan Pancasila, pelaksanaan Undang-Undang Dasar Negara Republik Indonesia Tahun 1945, pelestarian Bhinneka Tunggal Ika serta pemertahanan dan pemeliharaan keutuhan Negara Kesatuan Republik Indonesia;

b. pembinaan persatuan dan kesatuan bangsa;

c. pembinaan kerukunan antar suku dan intrasuku, umat beragama, ras, dan golongan lainnya guna mewujudkan stabilitas keamanan lokal, regional, dan nasional;

d. penanganan konflik sosial sesuai ketentuan peraturan perundang-undangan.

11 Ali Marwan Hsb, Op. cit., hlm. 172. 
e. koordinasi pelaksanaan tugas antar instansi pemerintahan yang ada di wilayah daerah provinsi dan daerah kabupaten/kota untuk menyelesaikan permasalahan yang timbul dengan memperhatikan prinsip demokrasi, hak asasi manusia, pemerataan, keadilan, keistimewaan dan kekhususan, potensi serta keanekaragaman daerah sesuai dengan ketentuan peraturan perundang-undangan;

f. pengembangan kehidupan demokrasi berdasarkan Pancasila; dan

g. pelaksanaan semua urusan pemerintahan yang bukan merupakan kewenangan daerah dan tidak dilaksanakan oleh instansi vertikal. 12

\section{Potensi Permasalahan dalam Hubungan Vertikal Pemerintah Pusat dan Daerah dalam Undang-Undang Nomor 23 Tahun 2014}

Dalam pelaksanaan UU No. 23/2014, beberapa persoalan amat mungkin untuk muncul, meskipun masih dalam tataran normatif yuridis. Beberapa potensi persoalan tersebut mengindikasikan masih dominannya (masih bersifat sangat vertikal) kekuasaan Pemerintah Pusat dalam berbagai urusan dalam tata kelola urusan pemerintahan, yaitu: ${ }^{13}$

1. Pembagian jenis urusan pemerintahan konkuren antara pemerintah pusat, provinsi, dan kabupaten/kota menggunakan kriteria dan skala tertentu. Namun pola seperti ini masih cukup sulit dilakukan sejak rejim pelaksanaan UU No. 32/2004 terutama untuk menentukan mana urusan yang menjadi kewenangan provinsi dan kabupaten/kota. Meskipun rincian jenis-jenis urusan sudah diatur dalam Lampiran UU No. 23/2014.

2. Perpindahan urusan pemerintahan konkuren antar tingkat pemerintahan terutama antara provinsi dan kabupaten/kota amat sulit untuk dilakukan mengingat infrastruktur dan struktur di daerah kabupaten/kota sudah berfungsi cukup lama, sepanjang UU No. 32/2004 berlaku. Apalagi pola pembagian urusan pemerintahan di daerah dalam UU No. 23/2014 amat berbeda. Banyak urusan pemerintahan yang dulunya dipegang oleh kabupaten/kota ditarik menjadi kewenangan pemerintah

12 Yusid Toyib dan Riant Nugroho, Transformasi Public Private Partnership Indonesia Oleh, Jakarta: Elex Media Komputindo, 2018, hlm. 81. Lihat juga di M. Yasin Nahar Djambar dan Muhammad Tavip, "Penyelenggaraan Urusan Pemerintahan Bidang Pertambangan dalam Perspektif Otonomi Daerah", eJurnal Katalogis, Volume 5, Nomor 2, Februari 2017, hlm 26-35

13 Dinoroy Marganda Aritonang, "Pola Distribusi Urusan Pemerintah Daerah Pasca Berlakunya UndangUndang Nomor 23 Tahun 2014 tentang Pemerintahan Daerah”, Jurnal Legislasi Indonesia, Vol. 13, No. 01, Maret 2016, hlm. 49. 
provinsi (sebagai wakil/representasi dari pemerintah pusat). Hal ini menegaskan hubungan antar pemerintahan daerah yang semakin terlihat hierarkis.

3. Tidak tegasnya diatur dalam UU No. 23/2014 mengenai urusan pemerintahan yang amat mungkin muncul dalam pelaksanaan atau harus diatur oleh daerah namun belum diatur dalam UU tersebut. UU No. 23/2014 belum memberikan prosedur bagaimana jika daerah hendak atau berkeinginan untuk mengatur urusan tersebut.

4. Hal yang baru dalam penyelenggaraan urusan pemerintahan daerah yang sifatnya konkuren adalah munculnya terminologi "urusan pemerintahan konkuren yang sifatnya wajib namun tidak terkait pelayanan dasar". Hal ini cukup aneh sebab dalam UU No. 32/2004 tidak dikenal sebelumnya. Dalam UU No. 23/2014 disebutkan apa yang dimaksud dengan pelayanan dasar, yaitu: pelayanan publik untuk memenuhi kebutuhan dasar warga negara. Namun, UU tidak memberikan penjelasan lebih lanjut bentuk empiris seperti apa urusan wajib yang tidak terkait pelayanan dasar tersebut. Urusan wajib konkuren yang terkait pelayanan dasar hanya dibatasi pada 6 jenis urusan saja.

5. Dilihat dari jenis urusan konkuren, ada beberapa jenis urusan wajib yang tidak terkait pelayanan dasar namun sebenarnya jika dipahami justru akan membutuhkan penyediaan pelayanan dasar dari pemerintah daerah kepada masyarakat. Sebagai contoh, urusan pangan, urusan administrasi kependudukan dan pencatatan sipil, urusan perpustakaan, dan urusan pengendalian penduduk dan keluarga berencana. Padahal jenis urusan-urusan tersebut dalam UU No. 32/2004 dapat dikatakan sebagai urusan yang sifatnya wajib diberikan oleh daerah kepada masyarakat dan sifatnya merupakan pelayanan dasar.

6. Kerancuan pada UU No. 23/2014 adalah batasan atau pengertian "urusan pemerintahan pilihan". Urusan Pemerintahan Pilihan adalah Urusan Pemerintahan yang wajib diselenggarakan oleh Daerah sesuai dengan potensi yang dimiliki Daerah. Poin utama yang menjadi persoalan adalah bagaimana jika daerah memiliki sejumlah potensi yang terkait dengan salah satu atau beberapa jenis urusan pilihan sebagaimana yang diatur dalam UU tersebut namun daerah merasa belum siap untuk menjalankannya. 


\section{Aspek Yuridis Hubungan dan Kewenangan Vertikal dalam Tata Kelola Pemerintahan}

Antara Pemerintah Pusat dan Daerah

\section{Asas Penyelenggaraan Pemerintahan dalam Tata Kelola Pemerintahan Antara Pusat dan Daerah}

UU No. 32/2004 mengatur bahwa dalam menyelenggarakan pemerintahan, Pemerintah menggunakan 3 (tiga) asas yaitu: desentralisasi, tugas pembantuan, dan dekonsentrasi sesuai dengan peraturan perundang-undangan. Selanjutnya, dalam penjelasan umum undang-undang Nomor 23 tahun 2014 secara tersurat tidak ada pernyataan bahwa otonomi daerah dilaksanakan secara nyata dan bertanggung jawab seperti halnya tercantum dalam penjelasan Undang-Undang Nomor 32 tahun 2004. Terkait dengan tanggung jawab, Undang-Undang Nomor 23 Tahun 2014 menitikberatkan otonomi daerah dengan tanggung jawab akhir di tangan presiden. Konsekuensinya Presiden berkewajiban untuk melakukan pembinaan dan pengawasan terhadap penyelenggaraan Pemerintahan Daerah. Sedangkan dalam menyelenggarakan urusan pemerintahan, yang menjadi kewenangan daerah, pemerintahan daerah menjalankan otonomi seluas-luasnya untuk mengatur dan mengurus sendiri urusan pemerintahan berdasarkan asas otonomi dan tugas pembantuan. ${ }^{14}$

\section{Mekanisme Pengawasan dalam Hubungan dalam Tata Kelola Pemerintahan Antara Pusat dan Daerah}

Hubungan antara pemerintah pusat dengan pemerintah daerah ditentukan dalam sistem pengawasannya. Berdasarkan sistem pengawasan inilah terbentuk tata hubungan pemerintahan dalam suatu negara. ${ }^{15}$ Dasar hubungan antara pusat dan daerah adalah bahwa pemerintah pusat menyerahkan sebagian wewenang pemerintahannya kepada daerah untuk diatur dan diurus sendiri sebagai urusan rumah tangga daerah (otonom). ${ }^{16}$ Merujuk pada pendapat Bagir Manan bahwa terdapat dua model pengawasan terkait pemerintahan otonomi, yaitu pengawasan preventif (prevenef toezicht) dan pengawasan represif (repressief toezicht). ${ }^{17}$ Kedua model pengawasan ini ditujukan pada produk hukum yang dihasilkan daerah, dan

14 Ibid., hlm. 46.

15 Samuel Humes IV, Local Governance and National Power, London: IULA, 1991, hlm. 4-7. Dalam Hhanif Nurcholis, "Hubungan Tata Pemerintahan Antara Pemerintah Pusat dan Pemerintah Daerah", Jurnal Studi Pemerintahan, Universitas Muhammadiyah Yogyakarta, Vol. 2, No. 2 Agustus 2011, hlm. 2

16 Widodo Ekathahjana, Pengujian Peraturan Perundang-undangan dan Sistem Peradilannya di Indonesia, Jakarta: Pustaka Sutra, 2008. hlm. 39. Dalam Mohamad Khamim, Peran DPRD dalam Mewujudkan Good Governance di Daerah, Pekalongan: Nasya Expanding Management, 2021, hlm. 38.

17 Ibid., hlm. 43. 
pengawasan terhadap tindakan tertentu dari organ pemerintahan daerah yang dilakukan melalui wewenang mengesahkan (goedkeuring) dalam pengawasan preventif maupun wewenang pembatalan (vernieging) atau penangguhan (schorsing) dalam pengawasan represif 18 .

Apabila model pengawasan di atas dikaitkan dengan implementasi pengawasan peraturan daerah sebagai salah satu produk penyelenggaraan pemerintahan otonomi, maka model pengawasan preventif ini dilakukan dengan pemberian pengesahan atau penolakan pengesahan peraturan daerah (perda) yang disusun oleh pemerintahan daerah (pemda). Pengawasan yang dilakukan oleh pemerintah pusat kepada daerah merupakan pengawasan internal yang hanya berada pada ranah eksekutif saja. Dalam pengawasan preventif, perda yang dihasilkan hanya dapat berlaku apabila telah terlebih dahulu disahkan oleh penguasa yang berwenang mengesahkan. ${ }^{19}$ Model pengawasan preventif ini pada prinsipnya hanya dilakukan terhadap perda yang mengatur sejumlah materi-materi tertentu yang ditetapkan sebelumnya melalui peraturan perundang-undangan. ${ }^{20}$

Pemerintahan daerah bersifat dependent dan subordinate terhadap pemerintahan pusat yang mempunyai kewenangan melakukan pembinaan dan pengawasan terhadap pemerintahan daerah, agar dalam penyelenggaraan pemerintahan tidak menyimpang dari sistem pemerintahan pusat, tidak melakukan tindakan yang bertentangan dengan kebijakan pemerintah pusat, dan tidak membuat kebijakan yang bertendensi pada keinginan memisahkan diri dari NKRI. Dengan adanya pembinaan dan pengawasan oleh pemerintah pusat, pemerintah daerah dapat menyelenggarakan pemerintahannya sendiri sesuai dengan koridor konstitusi dan undang-undang dalam sistem pemerintahan nasional dan dapat mencapai tujuan negara pada tingkat daerah secara efektif dan efisien. ${ }^{21}$ Pembatasan dalam pengawasan kewenangan daerah mencakup pula pembatasan macam atau bentuk pengawasan. Suatu pengawasan akan memiliki fungsi kontrol apriori kepada pengawasan tersebut dilakukan sebelum keluarnya suatu keputusan atau ketetapan pemerintah daerah. Di sini tampak jelas unsur preventif kontrol

18 Derita Prapti Rahayu, "Pengawasan Preventif sebagai Kontrol Pusat terhadap Daerah di Era Reformasi", Padjadjaran Jurnal Ilmu Hukum, Volume 2 Nomor 3 Tahun 2015, hlm. 451.

19 Ibid.

20 I.G.E. Budiputra, Dualisme Pembatalan Peraturan Daerah Provinsi dengan Peraturan Presiden \& Peraturan Menteri Dalam Negeri. Tesis. Bali: PPS Universitas Udayana, 2015, hlm. 100.

21 Derita Prapti Rahayu, Yokotani, dan Darwance, Laporan Akhir Kajian dan Evaluasi Pancasila sebagai Kaidah Penuntun untuk Undang-Undang Nomor 23 Tahun 2014 tentang Pemerintah Daerah, JakartaBangka Belitung: Badan Pembinaan Ideologi Pancasila (BPIP) dan Fakultas Hukum Universitas Bangka Belitung (FH UBB) Desember 2019, hlm. 17. 
tersebut memiliki tujuan utama berupa pencegahan terjadinya suatu kesalahan dalam praktik pengambilan keputusan. ${ }^{22}$

Terkait dengan pembatalan kebijakan daerah poin penting yang harus menjadi perhatian para pembuat kebijakan daerah, adalah hal-hal sebagai berikut:

1. Dalam penyusunan kebijakan daerah maka harus ditinjau perihal keterpaduan antara Pasal 17 dan Pasal 251 Undang-Undang Nomor 23 Tahun 2014, bahwa kebijakan daerah yang dirumuskan dalam bentuk peraturan daerah dan peraturan kepala daerah akan dibatalkan karena bertentangan dengan ketentuan peraturan perundang-undangan yang lebih tinggi, kepentingan umum, dan/atau kesusilaan serta bertentangan dengan Norma, Standar, Prosedur dan Kriteria yang telah ditetapkan oleh Pemerintah Pusat.

Akan tetapi pada sisi yang lain, menurut hemat penulis terdapat inkonsistensi Pasal 251 dan Pasal 17 ayat (3) UU Nomor 23 tahun 2014. Dimana pada Pasal 17 ayat (3) diatur bahwa Presiden yang dibantu Wakil Presiden dan Menteri dapat membatalkan kebijakan daerah. Hal ini dapat dipahami bahwa kekuasaan presiden sebagai kepala pemerintahan dapat secara langsung membatalkan peraturan daerah (Perda), peraturan kepala daerah dan keputusan kepala daerah yang jika dicermati perbandingannya dengan mekanisme pembatalan berjenjang yang di atur pada Pasal 251 UU No.23 tahun 2014.

2. Dengan memperhatikan Pasal 17 Undang-Undang Nomor 23 Tahun 2014 khusus untuk kebijakan daerah yang berbentuk keputusan kepala daerah dibatalkan karena bertentangan dengan Norma, Standar, Prosedur dan Kriteria yang telah ditetapkan oleh Pemerintah Pusat. Hal ini jelas tidak sinkron dengan Pasal 66 yang menyatakan bahwa keputusan hanya dapat dibatalkan apabila terdapat cacat wewenang; prosedur; dan/atau substansi. Frasa "hanya dapat dibatalkan" menunjukkan bahwa tidak ada alasan lain yang dapat membatalkan keputusan kepala daerah di luar ketiga alasan di atas. Sedangkan pada Pasal 17 juga mengakomodasi pembatalan keputusan kepala daerah dapat dilakukan jika bertentangan dengan Norma, Standar, Prosedur dan Kriteria yang telah ditetapkan oleh Pemerintah Pusat. Kontra posisi antara pasal 17 dan pasal 66 ini tidak hanya kan menimbulkan tafsir yang berbeda, tetapi juga dapat menjadi semacam "standar

22 King Faisak Sulaiman, Dialekka Pengujian Peraturan Daerah Pasca Otonomi Daerah, Yogyakarta: Pustaka Pelajar, 2014, hlm. 46. 
ganda" dalam mekanisme pembatalan suatu kebijakan daerah. Disisi lain, kontra posisi ini makin menegaskan bahwa secara filosofis nuansa sentralistis oleh pemerintah pusat masih sangat kental.

Oleh karena itu, ketidaksinkronan antara Undang-Undang Nomor 23 tahun 2014 tentang Pemerintahan Daerah dan Undang-Undang Nomor 30 Tahun 2014 tentang Administrasi Pemerintahan, perlu dievaluasi dan dilakukan harmonisasi terutama rumusan penormaan yang terkait dengan kebijakan daerah agar tidak menimbulkan ketidakpastian hukum dan dapat dilaksanakan secara efektif dan efisien dalam praktik teknisnya di daerah.

\section{Kesimpulan}

Hubungan kewenangan antara pemerintah pusat dan daerah sebagaimana yang diatur dalam UU No. 23 Tahun 2014 tidak mencerminkan otonomi luas karena hubungan tata kelola pemerintahan antara pemerintah pusat dan daerah lebih banyak masih bersifat vertikal. Hal ini disebabkan oleh faktor Undang-Undang Pemda yang baru tidak menerapkan residual function atau prinsip sisa yang benar-benar memberikan kewenangan otonomi yang sangat luas (general competence) dan Pembagian urusan pemerintahan sebagaimana yang diatur di dalam UU No. 23 Tahun 2014 lebih cenderung kepada ajaran sistem rumah tangga material dan sistem rumah tangga riil. Di satu sisi terdapat pembagian urusan pemerintahan yang rinci antara urusan pemerintahan absolut, konkuren, dan umum, dengan pembedaan yang tegas antara tiap tingkatan pemerintah yang merupakan ciri dari sistem rumah tangga material. Selain itu, hubungan kewenangan pemerintah dalam tata kelola pemerintahan antara pusat dan daerah maka secara yuridis bahwa Dalam UUD 1945 hubungan pusat dan daerah mencakup hubungan wewenang, keuangan, pelayanan umum, sumber daya alam, dan sumber daya lainnya. Urusan Pemerintahan yang diserahkan ke Daerah berasal dari kekuasaan pemerintahan yang ada pada Presiden. Konsekuensi suatu negara kesatuan adalah tanggung jawab akhir pemerintahan ada ditangan Presiden. dan Konteks pembinaan dan pengawasan oleh Presiden (pemerintah pusat) terhadap penyelenggaraan pemerintahan daerah sebagaimana diatur UU No. 23 Tahun 2014 dalam pelaksanaannya tidak mengurangi/membelenggu kemandirian daerah akan tetapi harus dalam koridor yang adil dan merata, untuk menghindari disintegrasi dan konflik horizontal antara rakyat/masyarakat dengan Negara utamanya terkait distribusi atas pengelolaan sumber daya alam kepada daerah. Aspek yuridis mengenai hubungan dan kewenangan pemerintah pusat dan daerah, masih terdapat beberapa potensi persoalan tersebut mengindikasikan masih 
dominannya (masih bersifat sangat vertikal) kekuasaan Pemerintah Pusat dalam berbagai urusan dalam tata kelola urusan pemerintahan seperti pada uraian pada pembahasan, sehingga perlu dirumuskan formulasi hukum yang tepat, untuk menghindari kerancuan dan kekosongan hukum.

\section{Daftar Pustaka}

\section{Buku}

Budiputra, I.G.E., Dualisme Pembatalan Peraturan Daerah Provinsi dengan Peraturan Presiden \& Peraturan Menteri Dalam Negeri. Tesis. Bali: PPS Universitas Udayana, 2015.

Ekathahjana, Widodo, Pengujian Peraturan Perundang-undangan dan Sistem Peradilannya di Indonesia, Jakarta: Pustaka Sutra, 2008.

Hsb, Ali Marwan, Keberadaan Mahkamah Konstitusi dan Putusannya, Medan: Enam Media, 2019. Humes IV, Samuel, Local Governance and National Power, London: IULA, 1991.

Khamim, Mohamad, Peran DPRD dalam Mewujudkan Good Governance di Daerah, Pekalongan: Nasya Expanding Management, 2021.

Manan, Bagir, Menyongsong Fajar Otonomi Daerah, Yogyakarta: Penerbit Pusat Studi Hukum FH UII, 2001.

Marzuki, Peter Mahmud, Penelitian Hukum, edisi revisi cetakan Ke-13, Jakarta: Kencana, 2017.

Novianto, Widhi dkk., Isu-isu Strategis Bidang Desentralisasi dan Otonomi Daerah, Jakarta: Pusat Kajian Desentralisasi dan Otonomi Daerah, 2016.

Rahayu, Derita Prapti, Yokotani, dan Darwance, Laporan Akhir Kajian dan Evaluasi Pancasila sebagai Kaidah Penuntun untuk Undang-Undang Nomor 23 Tahun 2014 tentang Pemerintah Daerah, Jakarta-Bangka Belitung: Badan Pembinaan Ideologi Pancasila (BPIP) dan Fakultas Hukum Universitas Bangka Belitung (FH UBB) Desember 2019.

Ridwan, H.R., Hukum Administrasi Negara, Yogyakarta: UII Press.

Sulaiman, King Faisak, Dialekka Pengujian Peraturan Daerah Pasca Otonomi Daerah, Yogyakarta: Pustaka Pelajar, 2014.

Toyib, Yusid dan Riant Nugroho, Transformasi Public Private Partnership Indonesia Oleh, Jakarta: Elex Media Komputindo, 2018.

Wingyosoebroto, Soentandyo, Penelitian Hukum, Surabaya, Surabaya: Pusat Studi Hukum dan Pembangunan Fakultas Hukum UNAIR, 1974. 


\section{Jurnal dan Makalah}

Aritonang, Dinoroy Marganda, "Pola Distribusi Urusan Pemerintah Daerah Pasca Berlakunya Undang-Undang Nomor 23 Tahun 2014 tentang Pemerintahan Daerah", Jurnal Legislasi Indonesia, Vol. 13, No. 01, Maret 2016.

Djambar, M. Yasin Nahar dan Muhammad Tavip, "Penyelenggaraan Urusan Pemerintahan Bidang Pertambangan dalam Perspektif Otonomi Daerah", eJurnal Katalogis, Volume 5, Nomor 2, Februari 2017.

Nurcholis, Hanif, "Hubungan Tata Pemerintahan Antara Pemerintah Pusat dan Pemerintah Daerah", Jurnal Studi Pemerintahan, Universitas Muhammadiyah Yogyakarta, Vol. 2, No. 2 Agustus 2011.

Rahayu, Derita Prapti, "Pengawasan Preventif sebagai Kontrol Pusat terhadap Daerah di Era Reformasi", Padjadjaran Jurnal Ilmu Hukum, Volume 2 Nomor 3 Tahun 2015.

Rasyid, Ryaas, “UU No. 23/2014 Membelokan Arah Otonomi Daerah dari Pakem Reformasi 1999”, Pidato Sebagai Keterangan Ahli Sidang Mahkamah Konstitusi atas Pengajuan Judicial Review atas UU No. 23 Tahun 2014 tentang Pemerintahan Daerah, 14 April 2016.

Said, Abdul Rauf Alauddin, "Pembagian Kewenangan Pemerintah Pusat-Pemerintah Daerah dalam Otonomi Seluas-Luasnya Menurut UUD 1945”, Fiat Justisia Jurnal Ilmu Hukum Volume 9 No. 4, Oktober-Desember 2015.

\section{Situs Internet}

Dhesinta, Wafia “Pembagian Kewenangan Pusat dan Daerah Berdasarkan UUD 1945 dan Prinsip Otonomi Daerah", Academia.edu, https://www.academia.edu/14842154/pembagian_ kewenangan_pusat_dan_daerah_berdasarkan_uud_1945_dan_prinsip_otonomi_daerah, diakses pada tanggal 26 Januari 2021

Naskah Akademik RUU tentang Pemerintahan Daerah, Kementerian Dalam Negeri Republik Indonesia, 2011, dikutip dari www.rumahpemilu.com, diakses tanggal 18 Maret 2014. 